\title{
Assessment of CSR Practices in Nepalese Commercial Banks (A Comparative Study of RBBL, SCBL \& NABIL)
}

\section{Abstract}

\author{
Kapil Khanal ${ }^{*}$
}

Objective: To assess the corporate social responsibility practices in Nepalese commercial banking sector.

Methods and Materials: Primary and secondary sources of data were used in the study. The primary data were collected through direct questionnaire method from 60 employees of sampled commercial banks. The secondary source was through journals, textbooks and annual reports of Nepal Rastra Bank. SPSS and Microsoft excel were used to analyze the collected data. The value of Cronbach's Alpha ( $\alpha$ ) of overall questionnaire is 0.92, which suggests the reliability of primary data. Descriptive and explorative research designs were used to analyze the primary and secondary data.

Results and Conclusion: Responses from all the respondents of commercial banks regarding CSR and Non-Financial Performance clearly imply that CSR has an influence on the NonFinancial Performance. In terms of ' $\mathrm{R}^{2}$, CSR impacts both Brand Image and Brand Awareness (i.e. 0.987). This clearly indicates that more than $98.7 \%$ variance of both non-financial performances has been explained by CSR. In terms of ' $\mathrm{R}^{2}$ ', CSR impacts less in financial performance (i.e. 0.149 ). This clearly indicates that only than $14.9 \%$ variance of financial performance has been explained by CSR.

Article type: Research Paper

Keywords: Corporate Social Responsibility, Commercial Banks, Financial Performance, Nonfinancial Performance

* Dr. Khanal is an Associate Professor at Tribhuvan University, Faculty of Management, Shanker Dev Campus Email: kapilkhanal848@gmail.com 


\section{Background}

Traditionally, business firms have focused on 'profit making' (Sandhu \& Kapoor, 2005) but in recent years, there has been an increased pressure on businesses to practice and demonstrate their responsibilities towards the society (Miittal, 2007). It is no longer enough for an enterprise to simply employ people, make profits, and pay taxes (Sandhu \& Kapoor, 2005; Mittal, 2007). A visionary corporation that looks to sustain in the long run operates on an unfailing set of core values and lasting purpose that go beyond merely making money (Mittal, 2007). Corporate are regarded as social institutions (Sandhu \& Kapoor, 2005) and are rather perceived to be inseparable from the societies they operate within (Holme, 2010; Mittal, 2007). They are now expected to be accountable and possess an interest in meeting individual as well as social needs (Green \& Peloza, 2011).

Corporate Social Responsibility is an evolving term that does not have a standard or specified definition. With the understanding that businesses are mandatory in job and wealth creation, CSR is generally understood to be the way a business integrates economic, environmental, and social imperatives (Barakat et al., 2016). According to Holmes (2010), CSR often involves the initiatives that extend beyond the legal compliances. Moreover, CSR is a concept which includes ethically/morally 'desirable' or 'good' business practices and the way shareholders, employees, customers, suppliers, government, and other stakeholders are engaged/involved (Mittal, 2007; Green \& Peloza, 2011).

In Nepal, financial services sector commenced with the establishment of Nepal Bank Limited in 1937. After the liberalization in the mid-1980s, the government permitted the opening of commercial banks in joint venture with foreign banks. Since then, the Nepalese financial system has undergone major structural changes, with commercial banks being considered as key drivers of financial institutions, products and services (Jha \& Hui, 2012). Moreover, financial institutions don't just influence the profit/loss of their shareholders, but also drive the economy of the entire nation (Upadhyay \& Dhungel, 2013). Hence, they are accountable and obliged towards the society in which they operate.

Likewise, Corporate Social Responsibility has evolved with historical evidences that date back to over a century. However, today, many businesses in Nepal have deliberately chosen not to address it for all the wrong reasons (Sainju, 2016). Corporate Social Responsibility is understood simply as philanthropy of a business, which is only one form of CSR (Malla, 2008; Singh, 2015; Sainju 2016). The business community in Nepal still lacks the understanding that Corporate Social Responsibility can be incorporated without making sizable investment (Singh, 2015). CSR is perceived simply as an act of charity or a cost and compliance. However, the corporates in Nepal need to understand that CSR obligations can be met even without making sizable grants or additional investment (Sainju, 2016) and must be viewed not as an expense but as an investment that results in long-term gains (Malla, 2008). Again, Adhikari et al. (2016) reveals that in Nepal, establishing any business is a form of CSR as it creates jobs for people. Nevertheless, without political stability in the country it is difficult to invest in new businesses. 
Moreover, CSR has gained a momentum in Nepal, especially at times of natural calamities and disasters. While one side of the story shows large sums being invested on relief to the victims, the other portrays the ignorance of the same corporations on their responsibility towards their own employees and workers (Tuladhar, 2015). Therefore, CSR is beyond a mere act of philanthropy, but a strategically critical component of a business.

\section{Profiles of Sample Banks}

Rastriya Banijya Bank Ltd. (RBBL)

With its commencement in 1966, Rastriya Banijya Bank Ltd. is one of the pioneering financial institutions in Nepal. The fully government-owned bank has been running under the Bank and Financial Institution Act (BAFIA) and the Company Act. The bank has emerged as a strong financial institution with high public confidence, reflected in the highest deposit base and growing branch establishment in most parts of the nation; 192 branches (RastriyaBanijya Bank, 2013).

\section{Nabil Bank Ltd. (NABIL)}

Nabil Bank Ltd. is the first private sector bank in Nepal, commencing its operations since 1984. Nabil has extended international standard modern banking services through the 67 points of representation. With an introduction of innovating products and marketing concepts in the domestic banking sector, the bank has brought about an era of modern banking with customer satisfaction in Nepal (Nabil Bank, 2018).

\section{Standard Chartered Bank Ltd. (SCBL)}

Standard Chartered Bank Ltd., which began its operations since 1987, is the largest international bank currently established in Nepal. The bank is an integral part of the Standard Chartered Group with $29.79 \%$ of shares owned by the Nepalese public. With 15 points of representation, the bank is the initiator in the introduction of 'customer-focused' products and services in the country (Standard Chartered, 2017).

\section{Research Questions}

To achieve the affirmed aims and objectives, the following research questions have been formulated:

- What are the practices of Corporate Social Responsibility in Nepalese commercial banks?

- What are the major areas of CSR? Which is the most prioritized?

- What is the impact of CSR on financial and non-financial performances?

\section{Aims/ Objectives}

The following are the main aims and objectives of the study:

- To assess the scenario of Corporate Social Responsibility in sample banks of Nepal 
- $\quad$ To measure the impact of CSR practices on financial performances

- To analyze the impact of CSR on non-financial performances

\section{Literature Review}

The initial definition of CSR can be credited to Bowen (1953), who defined the term as the obligations of a business to pursue policies, decisions and lines of action that are desirable or good with respect to the values of the society (Barakat et al., 2016). Since then, various definitions for CSR have emerged (Barakat et al., 2016) making CSR an evolving term that is not limited to a standard definition (Mittal, 2007). CSR can be understood as the way economic, environmental and social imperatives are integrated by an enterprise while engaging the shareholders, employees, customers, suppliers, government, and other stakeholders (Mittal, 2007; Majumdar\& Saini, 2016). The central theme of the concept of CSR is that there are social forces that make corporates act in a certain way (Bhaduri\&Selarka, 2016). Regardless of the terminology, the core idea is that business should accept that it must play more than just an economic role in society (Robins, 2008).

The classical view of CSR was inclined towards maximization of profit, whereas another socioeconomic approach focused on going beyond profits inclusive of protecting and improving social welfare within and beyond the corporation (Adhikari, 2012). Thus, one of the most commonly accepted approaches to CSR was proposed and conceptualized by Carroll in 1979, with the use of a pyramid model that covered four CSR dimensions: economic, legal, ethical, and discretionary (Sandhu \& Kapoor, 2005; Adhikari, 2012; Barakat et al., 2016).

Failure to understand what stakeholders expect from the CSR implemented can lead to ineffective corporate practices (Pérez \& Bosque, 2014). Considering CSR as an investment decision, the concept has gained increased attention as an important part of the corporate marketing mix (Khan et al., 2015). According to Rangan et al. (2012) a dominant concept underlying corporate social responsibility is "centered on the idea of creating a shared value". The business, according to it, must seek to create value for shareholders such that it also creates value for society (Rangan et al., 2012).CSR is not limited to the impact business on society but encompasses a more complex relationship between business and society. The multidimensional nature of CSR means that a varying range of societal concerns will continue to affect the context within which businesses operate and the ability of businesses to pursue their activities successfully (Decker, 2004). Numerous controversial arguments have been put forward in association with the relationship of Corporate Social Responsibility with Corporate Financial Performance (Sandhu \& Kapoor, 2005). A number of studies have demonstrated the existence of a strong link between social imperatives and profitable performance (Popoli, 2011). A corporate can apply CSR to produce direct benefits for the bottom line through reduced risk, increased financial investment, improvements in a range of stakeholder outcomes and cost savings (Mittal, 2007; Smith \& Langford, 2011; Khan et al., 2015). Similarly, Kabir\& Thai (2017) assert that CSR may generate additional revenue directly or indirectly. The authors report that with growing awareness of social and environmental imperatives, CSR affects the purchase decisions of customers which in turn increases demand 
and loyalty even fostering price premium. Likewise, firms can experience cost reductions from the activities. CSR can impact employee motivation, productivity and loyalty, reducing the cost of turnover. Moreover, reduction in the cost of equity due to increased disclosures builds strong shareholders relationship (Kabir\& Thai, 2017).

\section{Conceptual Framework}

Based on the theoretical research and findings, the conceptual framework has been designed in alignment with one of the major research aims and objectives, such that, it seeks to evaluate the impact of CSR on financial and non-financial performances. In the framework, CSR is the 'independent variable' whereas Financial and Non-Financial Performances are the 'dependent variables'.

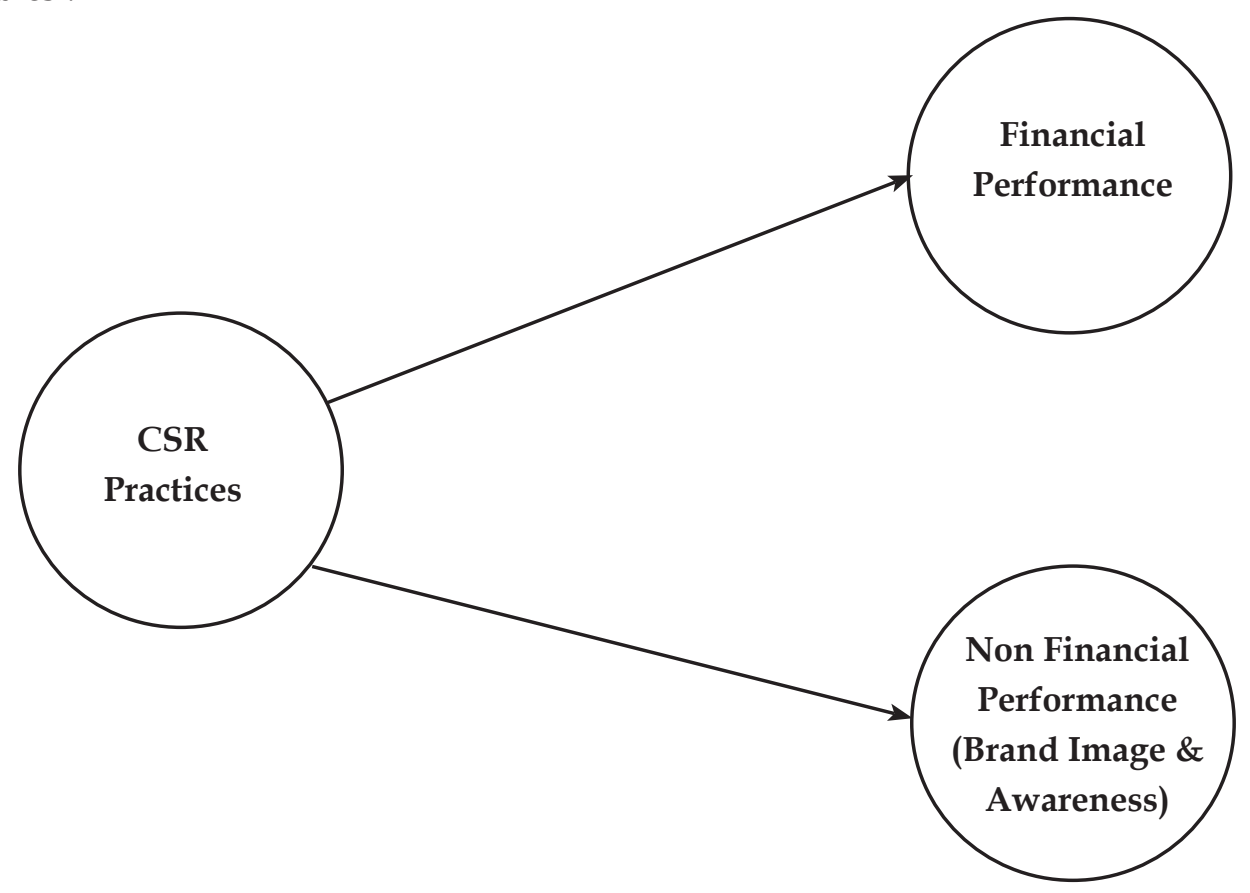

Figure 5: Conceptual Framework

This study looks to fill a research gap by assessing the scenario of CSR in financial service institutions, manifesting their outcomes, areas of prominence and impacts.

\section{Research Methodology}

Descriptive and exploratory approaches of research have been used in the study to identify and assess the implementation of CSR by sample banks and the areas of priority. The research approaches are both qualitative and quantitative. At the end of fiscal year, 2018, there are total of twenty-eight listed commercial banks in Nepal, which constitute the population of the study. For this study, only three commercial banks, i.e. Standard Chartered Bank Limited 
(SCBL), Nabil Bank Limited (Nabil) and RastriyaBanijya Bank Limited (RBBL) have been selected as sample banks. Selection of sample banks has been based on convenience and judgmental basis. Furthermore, an attempt has been made to include government bank and non-government bank. A questionnaire survey has been conducted for gathering the answers to the research questions.

Questionnaires were distributed to 20 top, middle and lower level employees of various departments of each sample bank, i.e. a total of 60 respondents from three banks. FivePoint Likert Scale has been extensively used to analyze and interpret the subjective answers of the respondents. Different statistical tools and techniques such as percentage, mean, standard deviation and coefficient of variance have been incorporated for the analysis and interpretation,. As a part of the analytical representation, correlation and linear regression have been used to examine the relationship between the variables, i.e. CSR with financial performance and non-financial performance. For the generation of the output, Microsoft Excel and SPSS programs have been used, extensively along with an analysis of the reliability of data. The following simple linear regression equations were used to measure the impact of CSR practices on financial and nonfinancial performances of commercial banks of Nepal:
FP
$=\beta_{0}$
$+\beta_{1} \mathrm{CSR}$
$+\ldots \ldots . .+$ et

Where, FP= Financial Performance, $\mathrm{CSR}=$ Corporate Social Responsibility
NFP
$=\beta_{0}$
$+\beta_{1} \mathrm{CSR}$
$+\ldots \ldots . .+$ et

Where, NFP= Nonfinancial Performance

\section{Data Analysis and Presentation}

Table: 1: Mean score of financial performance and impact of CSR by sample banks

\begin{tabular}{|l|c|c|c|}
\hline & RBBL & SCBL & NABIL \\
\hline The financial performance of the bank is related to CSR & 2.2 & 2 & 1 \\
\hline The impact of CSR on profitability of the bank is high & 2 & 1.6 & 1.1 \\
\hline Total & $\mathbf{4 . 2}$ & 3.6 & $\mathbf{2 . 1}$ \\
\hline Average (Mean) & $\mathbf{2 . 1}$ & $\mathbf{1 . 8}$ & $\mathbf{1 . 0 5}$ \\
\hline Standard Deviation & $\mathbf{0 . 1 4 1}$ & $\mathbf{0 . 2 8 3}$ & $\mathbf{0 . 0 7 1}$ \\
\hline Coefficient of Variation & $\mathbf{6 . 7 1}$ & $\mathbf{1 5 . 7 2}$ & $\mathbf{6 . 7 6}$ \\
\hline
\end{tabular}

Impact of CSR on Financial Performance has ranged between 1.8 (SCBL) and 2.1 (RBBL). Responses from all three commercial banks on CSR and Financial Performance clearly imply that CSR has no impact on Financial Performance. In all the banks, the value of standard deviation has been below 1 and coefficient of variation has been $6.71 \%$ to $15.72 \%$. This clearly indicates the mean is dependable. 
Table: 2 : Mean score of brand image and brand awareness by sample banks

\begin{tabular}{|c|c|c|c|}
\hline & RBBL & SCBL & NABIL \\
\hline Brand image of the bank is related to CSR & 4.8 & 4.9 & 4.85 \\
\hline Brand awareness is increased due to CSR & 4.5 & 4.7 & 4.6 \\
\hline Total & 9.3 & 9.6 & 9.45 \\
\hline Average (Mean) & 4.65 & 4.8 & 4.73 \\
\hline Standard Deviation & 0.212 & 0.141 & 0.177 \\
\hline Coefficient of Variance & 4.56 & 2.94 & 3.74 \\
\hline
\end{tabular}

Impact of CSR on Non-financial Performance has ranged between 4.65 (RBBL) and 4.8 (SCBL). Responses from all the respondents of commercial banks regarding CSR and Non-Financial Performance clearly imply that CSR has an influence on the Non-Financial Performance. Brand Image and Brand Awareness have scored over 4.5 which clearly indicate that the impact of CSR on these has been high. In all the banks, the value of standard deviation has been below 1 and coefficient of variation has been $2.94 \%$ to $4.56 \%$. This clearly indicates the representative nature of mean.

Table: 3: Regression result of brand image and brand awareness as dependent variables and corporate social responsibility as independent variable.

\begin{tabular}{|l|c|c|}
\hline Details & Brand Image & Brand Awareness \\
\hline Constant & -3.611 & -12.321 \\
\hline $\mathrm{b}$ (Coefficient) & 1.974 & 3.947 \\
\hline $\mathrm{R}$ & 0.993 & 0.993 \\
\hline $\mathrm{R}^{2}(\%)$ & 0.987 & 0.987 \\
\hline${ }^{\prime \prime} \mathrm{t}^{\prime}$ Value & 8.660 & 8.660 \\
\hline Significance & 0.073 & 0.073 \\
\hline
\end{tabular}

From simple observation of the table, it is clear that there exists a positive relationship between CSR and Brand Image and Brand Awareness i.e. value of ' $R$ ' in both case is 0.993. In terms of ' $\mathrm{R}^{2}$, CSR impacts both Brand Image and Brand Awareness (i.e. 0.987). This clearly indicates that more than $98.7 \%$ variance of both non-financial performances has been explained by CSR. In terms of " $\mathrm{t}$ " value, the relationship between CSR with both Brand Image and Brand Awareness is 8.660 i.e. significant at $5 \%$ level. Similarly, value of coefficient ' $b$ ' is positive in both cases. Results indicate that CSR is highly influential on non-financial performance of the banks with regard to brand image and awareness.

Table: 4: Regression result of financial performance as dependent variable and corporate social responsibility practices as independent variable.

\begin{tabular}{|l|c|}
\hline Details & Financial Performance \\
\hline Constant & 37.184 \\
\hline $\mathrm{b}$ (Coefficient) & -8.289 \\
\hline $\mathrm{R}$ & -0.386 \\
\hline $\mathrm{R}^{2}(\%)$ & 0.149 \\
\hline${ }^{\prime \prime} \mathrm{t}^{\prime}$ Value & -0.418 \\
\hline Significance & 0.748 \\
\hline
\end{tabular}


On simple observation of the table, it is clear that there exists a negative relationship between CSR and Financial Performance i.e. value of ' $R$ ' in both case is -0.386 . In terms of ' $\mathrm{R}^{2}$ ', CSR impacts less in financial performance (i.e. 0.149). This clearly indicates that only than $14.9 \%$ variance of financial performance has been explained by CSR. In terms of " $t$ " value, the relationship between CSR and financial performance is -0.418 at $5 \%$ level. Similarly, value of coefficient ' $b$ ' is negative. This indicates that CSR doesn't have any significant effect on financial performance of the banks.

\section{Conclusion}

This research was directed towards studying the practice of Corporate Social Responsibility in commercial banks of Nepal while determining the major areas and their prominence. The impact of CSR on business performance (financial and non-financial) was critically evaluated. To accomplish the aims and objectives, the study involved a collection and comparison of primary data from Rastriya Banijya Bank Ltd, Standard Chartered Bank Ltd. \& Nabil Bank Ltd. The sample constituted of 20 respondents from each bank.

The results manifest that all three commercial banks have understood the concept and the need of CSR and have incorporated strategies in the form of plans and policies, reporting and evaluation. Specific funds have been allocated while employee engagement has been highly promoted. Consequently, the overall performance of the banks in terms of CSR is satisfactory. The resources provided are primarily in the form of in-kind followed by volunteers and monetary grants or investments. Most importantly, the results distinctly indicated that Brand Awareness and Brand Image are highly impacted by CSR whereas the impact on Financial Performance is negligible.

To conclude, according to various authors, scholars and practitioners, it is neither practical nor logical for every business to practice the same form of CSR. CSR activities are found to be driven by diverse factors comprising of industries and markets, motivation from stakeholders and the business environment in which corporate functions and operates. The potential benefits of CSR imperatives undertaken can offset the costs while inclusion of philanthropy can reduce compliance and risks. Therefore, Corporate Social Responsibility, whether a cost, a charitable deed, a constraint, or a source of competitive advantage and opportunity; must be voluntary, not imposed upon and go beyond legal compliances. Corporate Social Responsibility must be implemented strategically while being embedded in the business' core strategy. Moreover, the impacts of CSR on a business might be positive yet sometimes variable. Nonetheless, "Corporate Social Responsibility is expected to last in the good times and the bad".

\section{References}

Adhikari, D. Gautam, D. \& Chaudhari, M. (2016). Corporate Social Responsibility Domains and Related Activities in Nepalese Companies. International Journal of Law and Management, [online] Volume 58 (6), p. 673-684. Available at: https:/ / doi.org/10.1108/IJLMA-082015-0044 [Accessed 10 Apr. 2018]. 
Adhikari, D. (2012). Status of Corporate Social Responsibility in Selected Nepalese Companies. Corporate Governance: The International Journal of Business in Society, [online] Volume 12 (5), p. 642-655. Available at: https:// doi.org/10.1108/14720701211275578 [Accessed 10 Apr. 2018].

Barakat, S. Isabella, G. Boaventura, J. \&Mazzon, J. (2016). The Influence of Corporate Social Responsibility on Employee Satisfaction. Management Decision, [online] Volume 54 (9), p. 2325-2339. Available at: https:// doi.org/10.1108/MD-05-2016-0308 [Accessed 10 Apr. 2018].

Bhaduri, S. \&Selarka, E. (2016). Corporate Social Responsibility Around the World - An Overview of Theoretical Framework, and Evolution. Corporate Governance and Corporate Social Responsibility of Indian Companies, [online] Chapter 2. Available at: http://www.springer.com/ [Accessed 10 Apr. 2018].

Decker, O. (2004). Corporate Social Responsibility and Structural Change in Financial Services. Managerial Auditing Journal, [online] Volume 19 (6), p. 712-728. Available at: https:/ / doi.org/10.1108/02686900410543840 [Accessed 10 Apr. 2018].

Green, T. and Peloza, J. (2011). How does corporate social responsibility create value for consumers? Journal of Consumer Marketing, [online] Volum 28 (1), p. 44-56. Available at: www.emeraldinsight.com/0736-3761.htm[Accessed 5 Dec. 2017].

Holme, C. (2010). Corporate Social Responsibility: A Strategic Issue or A Wasteful Distraction? Industrial and Commercial Training, [online] Volume 42 (4), p. 179-185. Available at: https://doi.org/10.1108/00197851011048528 [Accessed 10 Apr. 2018].

Jha, S. \& Hui, X. (2012). A Comparison of Financial Performance of Commercial Banks: A Case Study of Nepal. African Journal of Business Management, [online] Volume 6 (25), p. 7601-7611. Available at: http://www.academicjournals.org/AJBM [Accessed 10 Apr. 2018].

Kabir, R. \& Thai, H. (2017). Does Corporate Governance Shape The Relationship Between Corporate Social Responsibility and Financial Performance? Pacific Accounting Review, Volume 29 (2), p. 227-258. Available at: https://doi.org/10.1108/PAR-102016-0091[Accessed 17 Jun. 2018].

Khan, Z. Ferguson, D. \& Pérez, A. (2015). Customer Responses to CSR in the Pakistani Banking Industry. International Journal of Bank Marketing, [online] Volume 33 (4), p. 471-493. Available at: https://doi.org/10.1108/IJBM-07-2014-0097 [Accessed 10 Apr. 2018].

Majumdar, S. \& Saini, G. (2016). CSR in India: Critical Review and Exploring Entrepreneurial Opportunities.Journal of Entrepreneurship and Innovation in Emerging Economies, [online] Volume 2 (1), p. 56-79. Available at: http://eie.sagepub.com [Accessed 10 Apr. 2018].

Malla, K. (2008). Corporate Social Responsibility in Nepal. [online] The Himalayan Times. Available at: https://thehimalayantimes.com/opinion/topics-corporate-socialresponsibility-in-nepal/[Accessed 5 Apr. 2018]. 
Mittal, M. (2007). Corporate Social Responsibility: A New Way of Doing Business. Management and Labor Studies, [online] Volume 32 (2), p. 163-182. Available at: http://journals. sagepub.com [Accessed 10 Apr. 2018].

Nabil Bank. (2018). Introduction. [online] Available at: https://www.nabilbank.com/intro/ about-nabil-bank [Accessed 24 Jun. 2018].

Pérez, A. \& Bosque, I. (2014). Customer CSR Expectations in the Banking Industry. International Journal of Bank Marketing, [online] Volume 32 (3), p. 223-244. Available at: https:/ / doi.org/10.1108/IJBM-09-2013-0095 [Accessed 10 Apr. 2018].

Popoli, P. (2011). Linking CSR Strategy and Brand Image: Different Approaches in Local and Global Markets.Marketing Theory, [online] Volume 11 (4), p. 419-433. Available at: mtq.sagepub.com [Accessed 10 Apr. 2018].

Rangan, K., Chase, L. \& Karim, S. (2012). Why Every Company Needs a CSR Strategy and How to Build It. [online] Harvard Business School. Available at: www.hbs.edu [Accessed 10 Apr. 2018].

Rastriya Banijya Bank. (2013). Introduction. [online] Available at: https://www.rbb.com.np/ intro.php [Accessed 24 Jun. 2018].

Robins, F. (2008). Why Corporate Social Responsibility Should Be Popularized But Not Imposed? Corporate Governance: The International Journal of Business in Society, [online] Volume 8 (3), p. 330-341. Available at: https://doi.org/10.1108/14720700810879204 [Accessed 10 Apr. 2018].

Sainju, S. (2016). Corporate Social Responsibility: Issues for Business. [online] The Himalayan Times. Available at: https://thehimalayantimes.com/opinion/corporate-socialresponsibility-issues-businesses/[Accessed 5 Apr. 2018].

Sandhu, H. \& Kapoor, S. (2005). Corporate Social Responsibility and Financial Performance: Exploring the Relationship. Management and Labor Studies, [online] Volume 30 (3), p. 211-223. Available at: http:/ /journals.sagepub.com [Accessed 10 Apr. 2018].

Singh, S. (2015). CSR in Nepal. [online] My Republica. Availableat:http:/ / admin.myrepublica. com/opinion/story/33986/csr-in-nepal.html [Accessed 5 Apr. 2018].

Standard Chartered. (2017). About Us. [online] Available at: https://www.sc.com/np/aboutus/[Accessed 24 Jun. 2018].

Smith, V. \& Langford, P. (2011). Responsible or Redundant? Engaging the Workforce through Corporate Social Responsibility.Australian Journal of Management, [online] Volume 36 (3), p. 425-447. Available at: aum.sagepub.com [Accessed 10 Apr. 2018].

Tuladhar, S. (2015). Corporate Social Responsibility. [online] The Himalayan Times. Available at: https://thehimalayantimes.com/opinion/topics-corporate-social-responsibility/ [Accessed 5 Apr. 2018].

Upadhyay, K. and Dhungel, A. (2013). Corporate Social Responsibility Reporting Practices in the Banking Sector of Nepal. Banking Journal, [online] Volume 3 (1), p. 61-78. Available at: https://www.nepjol.info/index.php/BJ/article/view/7511 [Accessed 6 Jan. 2018]. 